\title{
$\Delta$ Np63a expression induces loss of cell adhesion in triple-negative breast cancer cells
}

\author{
Marta Nekulova', Jitka Holcakova', Xiaolian Gu², Vaclav Hrabal', Sotiris Galtsidis ${ }^{3}$, Paulina Orzol', Yajing Liu4, \\ Stella Logotheti ${ }^{3}$, Vassilis Zoumpourlis ${ }^{3}$, Karin Nylander ${ }^{2}$, Philip J Coates ${ }^{1}$ and Borivoj Vojtesek ${ }^{1 *}$
}

\begin{abstract}
Background: p63, a member of the p53 protein family, plays key roles in epithelial development and carcinogenesis. In breast cancer, p63 expression has been found predominantly in basal-A (epithelial-type) triplenegative breast carcinomas (TNBC). To investigate the functional role of p63 in basal-A TNBC, we created MDA-MB468 cell lines with inducible expression of the two major N-terminal p63 isoforms, TAp63a and $\triangle N p 63 a$.

Results: TAp63a did not have significant effect on gene expression profile and cell phenotype, whilst the main effect of $\Delta$ Np63a was reduction of cell adhesion. Gene expression profiling revealed genes involved in cell adhesion and migration whose expression relies on overexpression of $\Delta N p 63 a$. Reduced cell adhesion also led to decreased cell proliferation in vitro and in vivo. Similar data were obtained in another basal-A cell line, BT-20, but not in BT-549 basal-B (mesenchymal-like) TNBC cells.

Conclusions: In basal-A TNBC cells, $\triangle N$ p63a has much stronger effects on gene expression than TAp63a. Although p63 is mentioned mostly in connection with breast cell differentiation and stem cell regulation, we showed that a major effect of p63 is regulation of cell adhesion, a process important in metastasis and invasion of tumour cells. That this effect is not seen in mesenchymal-type TNBC cells suggests lineage-dependent functions, mirroring the expression of $\triangle N p 63 a$ in primary human breast cancers.
\end{abstract}

Keywords: p63 isoforms, Triple-negative breast cancer, Adhesion

\section{Background}

p63 is a member of the p53 family of transcription factors and is known to be involved in the regulation of epithelial development and carcinogenesis. The TP63 gene is expressed as a spectrum of protein isoforms due to alternative promoter usage and alternative splicing at the 3' end of the transcript [1]. There are two N-terminal protein isoforms: TAp63, containing a p53-like N-terminal transactivation domain, and $\Delta \mathrm{Np} 63$, the $\mathrm{N}$-terminally truncated isoform that lacks this transactivation domain. $\Delta$ Np63 was originally thought to be only a dominant negative inhibitor that blocks the function of full-length p53/p63/p73 proteins. Later it was found that $\Delta \mathrm{Np63}$ also

\footnotetext{
* Correspondence: vojtesek@mou.cz

${ }^{1}$ Regional Centre for Applied Molecular Oncology, Masaryk Memorial Cancer Institute, Zluty kopec 7, Brno 65653, Czech Republic

Full list of author information is available at the end of the article
}

transactivates target genes due to the presence of alternative transactivation domains $[2,3]$ and that it is the predominant isoform in most normal adult tissues according to immunohistochemical studies $[4,5]$. Compared to $\triangle \mathrm{Np63}$, TAp63 is expressed as the main isoform only in specific cell types such as germ cells and B-lymphocytes $[4,6,7]$. Similarly, $\Delta$ Np63 is overexpressed in many cancers, especially squamous carcinomas $[5,8]$ in contrast to TAp63 which is usually detected in tumour tissue at low level excepting B-cell lymphomas $[5,9]$.

In normal breast tissue, $\Delta \mathrm{Np} 63$ expression is restricted to basal/myoepithelial cells $[5,10,11]$ and p63 is essential for mammary gland morphogenesis during embryonic development [12]. In adulthood, $\Delta \mathrm{Np} 63$ is important for maintenance of basal cell characteristics of breast epithelial cells [13], for correct luminal cell proliferation and differentiation during lactation when it regulates paracrine 
basal-to-luminal cell signalling [14], and as a pro-survival factor of multipotent progenitor cells during postlactational involution [15]. $\Delta \mathrm{Np} 63$ expression is also linked with mammary stem cells - in mammary tissue $\Delta \mathrm{Np63}$ is expressed in the basal cell layer which is thought to contain stem cells [16], its expression was detected in activated stem cells isolated from developing mouse mammary tissue [17] and in stem cells isolated from mouse mammary epithelial cell line [18]. Moreover, Thomas et al. have isolated p63-positive stem cell-like multi-potent cells from breast milk [19] and $\mathrm{Li}$ et al. identified reciprocal interactions between p63 isoforms and hedgehog signalling in mammary stem and progenitor cells that regulate initiation and progression of the mammary regenerative cycle. In this situation, $\Delta \mathrm{Np} 63$ blocks and TAp63 promotes differentiation along the luminal lineage [20].

In breast cancer, $\Delta \mathrm{Np} 63$ is highly expressed in a subset of tumours with metaplastic and basal-like features that are frequently triple-negative [21-24]. Triple-negative breast cancers (TNBC) are defined by lack of estrogen receptor (ER), progesterone receptor (PR) and human epidermal growth factor receptor 2 (HER2). TNBC are highly proliferative, biologically more aggressive and exhibit poor prognosis compared to other types of breast cancer $[25,26]$. With no targeted treatments currently available, patients with TNBC have a high risk of relapse and shorter overall survival compared to other breast cancer subtypes [27].

Concerning the role of p63 in breast cancer cells, $\Delta \mathrm{Np} 63$ has been proposed as a pro-tumourigenic transcription factor that promotes cancer stem cell (CSC) features [21]. Consistent with this notion, $\Delta \mathrm{Np} 63$ promotes normal mammary stem cell activity by enhancement of Wnt signalling and through this mechanism governs tumour-initiating activity of basal-like breast cancer [28]. In general agreement with these findings, abrogation of endogenous $\Delta \mathrm{Np} 63$ causes a switch towards luminal phenotype and away from the basal phenotype in basal breast cancer cells, indicating a role in lineage regulation, although p63 silencing was insufficient to cause full luminal-type differentiation [29]. Further, $\Delta$ Np63 acts as a survival factor in a subset of breast cancers by antagonizing p73-mediated apoptosis [23]. In contrast, Buckley et al. have shown that $\Delta \mathrm{Np} 63$ cooperates with BRCA1 to regulate growth control and maintain genomic stability in normal breast cells [30]. They also suggested that defects in BRCA1- $\Delta$ Np63 signalling are key events in the pathogenesis of basal-like breast cancer. In agreement with this idea, $\Delta \mathrm{Np} 63$ and $\triangle \mathrm{Np73}$ up-regulate key DNA damage repair proteins (BRCA2, RAD50, RAD51, mre11, ATM) [31, 32] and loss of p63/p73 promotes mammary tumour formation in mice [33]. p63 has also been shown to play a tumour suppressor role in breast cancers because abrogation of its function through interaction with mutant p53-SMAD complex led to enhanced metastasis [34].

In view of the wide-ranging roles and effects of p63 that have been proposed in normal breast and TNBC, definitive roles for $\Delta \mathrm{Np} 63$ and TAp63 in basal-type breast cancer need to be clarified. In our work we further elucidated the role of these two p63 isoforms in TNBC cells.

\section{Methods}

Cell culture conditions, vectors and transfections, betagalactosidase assay

MDA-MB-468, BT-20 and BT-549 breast carcinoma cells were obtained from ATCC and maintained in Dulbecco's modified Eagle's medium (DMEM) supplemented with $10 \%$ fetal bovine serum (HyClone, Thermo Scientific, USA), $1 \mathrm{mM}$ sodium pyruvate (Sigma Aldrich, USA) and penicillin/streptomycin (HyClone, Thermo Scientific, USA) at $37^{\circ} \mathrm{C}$ in $\mathrm{CO}_{2}$ incubator in humidified atmosphere.

To generate clones with inducible expression of $\Delta \mathrm{Np} 63 \alpha$ and TAp63 $\alpha$, MDA-MB-468 cells were transfected with pcDNA6/TR (Life Technologies, USA) vector and selected with blasticidin $(5 \mu \mathrm{g} / \mathrm{ml})$ for three weeks. Resistant colonies were picked and expanded for further analysis under selective conditions. Beta-galactosidase assay was used to test the inducibility of stable transfectants. MDA-MB-468pcDNA6/TR cells were transiently transfected with $\mathrm{pT}$ REx/GW-30/lacZ vector (Life Technologies, USA), lacZ expression was induced by incubation in DMEM with $1 \mu \mathrm{g} / \mathrm{ml}$ tetracycline for $24 \mathrm{~h}$. Cells were fixed in PBS supplemented with $5 \mathrm{mM}$ EDTA, $20 \mathrm{mM} \mathrm{MgCl}$ and $0,2 \%$ glutaraldehyde for $10 \mathrm{~min}$, washed in PBS and incubated in staining buffer $(0,1 \mathrm{M}$ phosphate buffer supplemented with $2 \mathrm{mM} \mathrm{MgCl}_{2}, 5 \mathrm{mM}$ potassium ferrocyanide, $5 \mathrm{mM}$ potassium ferricyanide and $1 \mathrm{mg} / \mathrm{ml} \mathrm{X}$-gal substrate) for $30 \mathrm{~min}$ at room temperature. Development of blue colour was checked under light microscope. MDAMB-468-pcDNA6/TR cells were then transfected with pTREx-DEST30- $\Delta$ Np63 $\alpha$ and pT-REx-DEST30-TAp63 $\alpha$ vectors (containing full length cDNAs coding for human TAp $63 \alpha$ and $\Delta$ Np63 $\alpha$; prepared from pT-REx-DEST30 using Gateway cloning technology, both from Life Technologies, USA) and transfected cultures were selected with G418 (500 $\mu \mathrm{g} / \mathrm{ml})$ for three weeks. Resistant colonies were picked, expanded under selective conditions and tested for inducibility of p63 expression by Western blot. pcDNA3- $\triangle \mathrm{Np} 63 \alpha$ and pcDNA3-GFP vectors were used for transient transfections of BT-20 and BT-549, cells were analysed $24 \mathrm{~h}$ after transfection. All transfections were performed using Amaxa Nucleofector Technology (Lonza, Switzerland) according to the manufacturer's instructions.

\section{SDS-PAGE and Western blotting}

Cells were harvested directly into lysis buffer $(150 \mathrm{mM}$ $\mathrm{NaCl}, 1$ \% Nonidet P-40, $50 \mathrm{mM}$ Tris- $\mathrm{HCl} \mathrm{pH}$ 8.0, $5 \mathrm{mM}$ 
EDTA pH 8.0, protease inhibitor cocktail) and $20 \mu \mathrm{g}$ of total protein in NuPAGE LDS Sample Buffer (Life Technologies, USA) loaded on $10 \%$ polyacrylamide gels, separated and transferred onto nitrocellulose membranes in Mini-PROTEAN Electrophoresis System (Bio-Rad, USA) for $90 \mathrm{~min}$ applying $100 \mathrm{~V}$ in transfer buffer (240 mM Tris, 190 mM glycine, $20 \%$ methanol). Membranes were blocked in $5 \%$ non-fat milk in PBS with $0.1 \%$ Tween and incubated overnight with primary antibodies at $4{ }^{\circ} \mathrm{C}$. Primary antibodies used: anti-p63 clone SFI-6 (DCS Innovative Diagnostik-Systeme, Germany), anti-TAp63 clone TAp63-4.1 and anti- $\Delta$ Np63 clone $\Delta \mathrm{Np} 63-1.1$ and polyclonal $\Delta \mathrm{Np} 63-44$ [4] and anti-actin AC40 (Sigma-Aldrich, USA). Membranes were then incubated with appropriate HRP-conjugated secondary antibodies (RAM-Px, SWAR-Px, Dako, Denmark) diluted $1: 1000$ for $1 \mathrm{~h}$ at room temperature. Signal was detected using ECL reagent (Amersham Pharmacia Biotech, UK).

\section{Gene expression profiling}

MDA-MB-468 cells were cultured with $1 \mu \mathrm{g} / \mathrm{ml}$ tetracycline for $24 \mathrm{~h}$ and harvested. Total RNA was isolated using TRI Reagent (Sigma-Aldrich, USA) and 1-bromo-3-chloropropane, precipitated with ethanol and diluted in RNAsefree water. Total RNA was labelled using TargetAmp Nano Labeling Kit for Illumina Expression BeadChip (Illumina, USA) and subsequently used for genome-wide expression profiling using HumanHT-12 v4 Expression BeadChip Kit (Illumina, USA). Results were analysed using $R$ (The R Project for Statistical Computing), LIMMA software package [35], MultiExperiment Viewer [36] and GenomeStudio (Illumina, USA). Web tools from DAVID Bioinformatics Resources 6.7 [37] were employed to analyse gene ontology. The experiment was performed in three biological replicates.

\section{Quantitative RT-PCR}

For analysis of individual gene expression, cells were grown for $24 \mathrm{~h}$ in media with $1 \mu \mathrm{g} / \mathrm{ml}$ tetracycline. Total RNA was isolated using RNeasy Mini Kit (Qiagen, Netherlands). $1 \mu \mathrm{g}$ of total RNA was converted into cDNA using RevertAid H Minus Reverse Transcriptase (Thermo Fisher Scientific, USA). Quantitative RT-PCR was performed in technical triplicates using ABI 7900HT Fast Real Time PCR System (Applied Biosystems, USA) and repeated twice. Relative quantification of gene expression was performed in SDS 2.3 and RQ Manager 1.2 software (Applied Biosystems, USA) and RealTime StatMiner (Integromics, Spain). Primers are listed in Additional file 1.

\section{xCELLigence assay}

$x$ CELLigence system (ACEA Biosciences, USA) was used for real-time analysis of cell adhesion and proliferation. Before cells were seeded, background was measured
$45 \mathrm{~min}$ after adding $50 \mu \mathrm{l}$ media into each well of Eplate 16. Cells were trypsinized, resuspended in DMEM, counted using haemocytometer and 20000 cells in $100 \mu \mathrm{l}$ added per well. Impedance signal, which depends on the coverage of the electrodes with cells, was measured for $48 \mathrm{~h}$ in $15 \mathrm{~min}$ intervals. Tetracycline $(1 \mu \mathrm{g} /$ $\mathrm{ml}$ ) was added at the beginning of the experiment (time $0)$. Two independent experiments were performed, each sample was in triplicate.

\section{Cell detachment and wound-healing assays}

For cell detachment assay, cells were grown in 96-well plate for $24 \mathrm{~h}$ and then treated with $1 \mu \mathrm{g} / \mathrm{ml}$ tetracycline to induce p63 expression for 24 or $48 \mathrm{~h}$. After washing in $0.5 \%$ EGTA in PBS, cells were incubated in trypsin solution $(0.025 \%$ trypsin and $0.5 \%$ EGTA in PBS) for the indicated periods of time. Trypsinization was stopped by adding $100 \mu \mathrm{l}$ DMEM with $10 \%$ FBS. Cells were then washed in PBS, fixed in $4 \%$ paraformaldehyde for $10 \mathrm{~min}$, washed again in PBS and stained with crystal violet $(5 \mathrm{mg} / \mathrm{ml})$. After washing in tap water, cells were dried for $30 \mathrm{~min}$ at RT and then $2 \%$ SDS was used to dissolve the colour. Absorbance was measured at $595 \mathrm{~nm}$. Three independent experiments were performed, each sample was in hexaplicate.

For wound healing assay, cells were seeded in 6-well plates and cultured until confluent. Scratches were made using pipette tips and phase contrast images were taken with Eclipse Ti-E inverted microscope system (Nikon, Japan) for $48 \mathrm{~h}$ at $1 \mathrm{~h}$ intervals.

\section{Cell proliferation assay, viability assay and cell cycle analysis}

To compare cell proliferation, cells were grown for $24 \mathrm{~h}$ in 6-well plates and then treated with $1 \mu \mathrm{g} / \mathrm{ml}$ tetracycline to induce p63 expression. Both adherent and detached cells were harvested into $2 \mathrm{ml}$ of DMEM 0, 24, 48 and $72 \mathrm{~h}$ after tetracycline treatment and counted in haemocytometer. Three independent experiments were performed.

Propidium Iodide (PI) exclusion assay was used for measurement of cell viability after $0,24,48$ and $72 \mathrm{~h}$ treatment with $1 \mu \mathrm{g} / \mathrm{ml}$ tetracycline. Medium containing floating cells was removed and attached cells were trypsinized (efficiency of trypsinization was checked under the light microscope) and pooled with the floating cells. After addition of PI $(1 \mu \mathrm{g} / \mathrm{ml}$ final concentration) cells were analysed for red fluorescence by flow cytometry (FACSVerse, BD Biosciences, USA). The percentage of PI positive (dead) cells was determined, after exclusion of cell debris, using FACSuite software (BD Biosciences, USA). Two independent biological experiments were performed, each sample was in triplicate.

For cell cycle analysis, cells were treated with $1 \mu \mathrm{g} / \mathrm{ml}$ tetracycline for $24 \mathrm{~h}$, trypsinized, washed in PBS and 
fixed in $70 \%$ ethanol for $2 \mathrm{~h}$ on ice. After washing in PBS, cells were resuspended in $1 \mathrm{ml}$ of PI staining solution $(0.1 \%$ Triton X-100, $10 \mu \mathrm{g} / \mathrm{ml}$ PI, $100 \mu \mathrm{g} / \mathrm{ml}$ RNase $\mathrm{A}$ in PBS) and incubated at RT in the dark for $30 \mathrm{~min}$. Cell cycle analysis was performed with FACSVerse using FACSuite software (both BD Biosciences, USA) and ModFit LT 4.0 software (Verity Software House, USA). Two independent experiments were performed, each sample was in triplicate.

\section{Tumour xenografts}

$10^{6}$ cells were resuspended in $100 \mu \mathrm{l}$ PBS and injected subcutaneously into the left and right flanks of 6-week old female SCID mice. Mice were divided in 3 groups (MDA-MB-468 parental, MDA-MB-468- $\Delta$ Np63 $\alpha$ untreated and MDA-MB-468- $\Delta \mathrm{Np} 63 \alpha$ tetracycline treated). Tumours were allowed to grow for 3 weeks after the injections until tumour onset in all injected sites. Then, the group of MDA-MB-468- $\Delta$ Np63 $\alpha$ tetracycline treated mice were orally gavaged with $0.2 \mathrm{ml}$ of tetracycline solution $10 \mathrm{mg} / \mathrm{ml}$ to induce $\Delta \mathrm{Np} 63$ expression, on a daily basis for the next 8 weeks. During this period tumour volumes were measured using callipers and calculated using the formula $1 / 2 \mathrm{x}$ height $\mathrm{x}$ width $\mathrm{x}$ length. At the end of the observation period, mice were sacrificed, tumours excised and photographed.

\section{Results}

\section{Stably transfected cell lines with inducible expression of p63 isoforms}

To study the function of p63 in TNBC cells, we created an in vitro model that allows tight regulation of p63 expression. Because p63 is expressed predominantly in triple-negative and basal breast tumours with an epithelial phenotype (basal-A), MDA-MB-468 cell line was chosen as parental cell line. It has an ER-, PR-, HERphenotype and belongs to basal-A subtype of breast tumours [38] and basal-like BL1 subgroup of TNBC [39]. MDA-MB-468 cells are reported to express negligible levels of p63 according to gene expression profiling, RNA sequencing, qRT-PCR and western blot [40-42], although one study identified an undefined level of TAp63 mRNA in these cells without identifying p63 protein [43]. Because cell lines may show different properties in different laboratories due to differences in culture conditions, we therefore characterized our MDA-MB-468 cells for expression of p63 isoforms by qRT-PCR and immunochemical approaches using antibodies specific for all isoforms and mono-specific antibodies for TAp63 and $\triangle \mathrm{Np} 63$, showing a lack of all mRNA and p63 protein isoforms (Additional file 2). Clones stably transfected with tetracycline repressor were selected and their inducibility was subsequently tested by beta-galactosidase assay (Fig. 1a). Inducible
$\Delta \mathrm{Np} 63 \alpha$ and TAp63 $\alpha$ clones were subsequently prepared from this tetracycline-responsive clone by transfection with either pT-REx-DEST30- $\triangle \mathrm{Np} 63 \alpha$ or pTREx-DEST30-TAp63 $\alpha$ as described in the materials and methods section. Newly selected clones were tested for p63 isoform expression after tetracycline induction using the pan-p63 antibody SFI-6 that distinguishes the TA and $\Delta \mathrm{N}$ isoforms due to their different molecular weights and the isoform specific p63 antibodies (Fig. 1b, c), and the two clones named MDA-MB-468$\Delta \mathrm{Np} 63 \alpha$ and MDA-MB-468-TAp63 $\alpha$ were used for subsequent experiments. The parental clone expressing only tetracycline-regulated inhibitor of transcription was named MDA-MB-468-pcDNA6/TR and used as negative control (Fig. 1 also shows that these cells do not contain detectable levels of endogenous p63).

\section{$\triangle \mathrm{Np63a}$ regulates expression of adhesion-related genes in MDA-MB-468 cells}

To map gene expression changes after induction of $\Delta \mathrm{Np} 63 \alpha$ and TAp63 $\alpha$, MDA-MB-468 cells were treated with tetracycline for $24 \mathrm{~h}$ and total RNA was used for genome-wide expression analysis. By this method we identified 428 genes whose expression changes significantly (adjusted $\mathrm{p}$ values $<0.05$ ) after overexpression of $\triangle \mathrm{Np} 63 \alpha$ or TAp63 $\alpha$ (Additional file 3 ). In both cases, TP63 itself was the most highly up-regulated transcript and the identification of many previously reported p63 target genes (S100A2, FGFR3, GPX2, MIR205, KRT5 etc.) in this dataset indicate good informational value and reliability of this analysis and also of the inducible system. Contrary to expectations that both $\Delta \mathrm{Np} 63 \alpha$ and TAp63 $\alpha$ will affect gene expression, we found that only $\Delta \mathrm{Np} 63 \alpha$ significantly changed the gene expression profile, with TAp63 induction leading to up-regulation of only two genes, of which TP63 itself is one. According to gene ontology (GO) analysis of the $\Delta \mathrm{Np} 63 \alpha$-regulated genes, the most significantly enriched GO terms relating to biological processes were "cell adhesion" and "biological adhesion" $(p<0.001)$ (Fig. 2a). Other enriched adhesion-related GO terms were "cell-substrate adhesion" and "cell-matrix adhesion" $(p<0.05)$ indicating that cell-matrix adhesion was affected more than cellcell adhesion. Among GO terms describing subcellular localization of the gene product, "plasma membrane" was the most enriched term $(p<0.001)$ (Fig. 2b). This is in agreement with the assumption that many adhesionrelated proteins are transmembrane or membraneassociated. In accordance with this, many of the identified $\Delta \mathrm{Np} 63 \alpha$-regulated genes have been previously found to be involved in cell adhesion, motility, cytoskeleton dynamics, migration and invasion (listed in Fig. 2c). This group included genes related to cell-extracellular matrix (ECM) adhesion and focal adhesions such as 


\section{a}

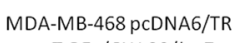
+ pT-REX/GW-30//acZ TET-

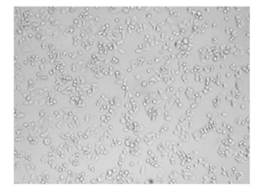

TET+

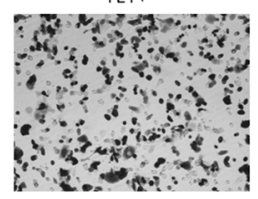

b

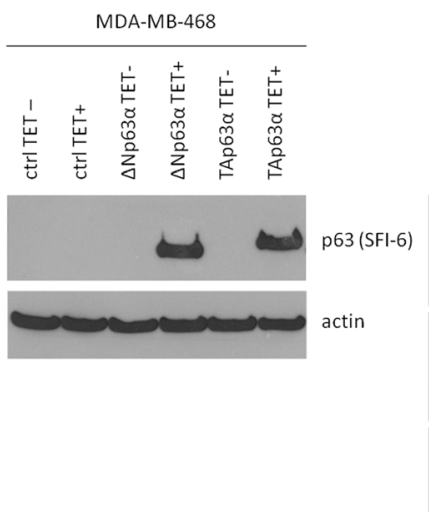

c

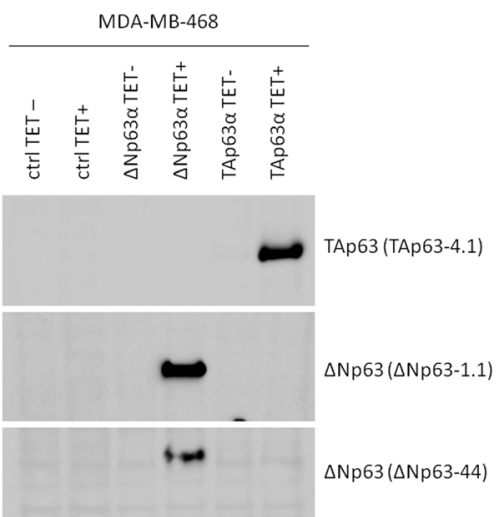

Fig. 1 MDA-MB-468 cells with inducible expression of p63 isoforms. a MDA-MB-468-pcDNA6/TR clone with stable expression of tetracycline repressor transiently transfected with vector encoding beta-galactosidase under control of tetracycline-inducible promoter; staining of beta-galactosidase activity $24 \mathrm{~h}$ after tetracycline (TET) treatment; $\mathbf{b}, \mathbf{c}$ Western blots of TAp63a and $\Delta \mathrm{Np63a}$ in MDA-MB-468- $\Delta$ Np63a and MDA-MB-468-TAp63a cells $24 \mathrm{~h}$ after tetracycline treatment; MDA-MB-468-pcDNA6/TR parental clone was used as a negative control

ITGB4 (integrin beta 4), ITGA2 (integrin alpha 2), FERMT1 (fermitin/kindlin), BAG3 (BCL2-associated athanogene 3), KLK5 (kallikerin-5), CLCA2 (chloride channel accessory 2), PALLD (palladin), SVIL (supervillin), TNS4 (tensin-4), TNS3 (tensin-3), LPXN (leupaxin), TLN2 (talin2) and CEACAM6 (carcinoembryonic antigen-related cell adhesion molecule 6). Genes encoding proteins regulating cell-cell adhesion include FAT2 (FAT tumour suppressor homolog 2), DSC3 (desmocollin-3), CLDN1 (claudin-1), CLDN8 (claudin-8), CLDN10 (claudin-10) and CGN (cingulin). Selected genes from this group were confirmed as $\triangle \mathrm{Np} 63 \alpha$-regulated by qRT-PCR analysis (Fig. $2 \mathrm{~d}$ ). Interestingly, we observed an opposite regulation of tensins TNS3 and TNS4, which are important for connection between cytoskeleton and integrins. It has been previously shown that inhibition of TNS4 expression decreases cell migration, while inhibition of TNS3 increases cell migration [44]. Moreover, TNS4 expression correlated with metastasis in invasive breast carcinomas. According to our results, $\triangle \mathrm{Np} 63 \alpha$ increases TNS4 and decreases TNS3 expression. Among identified $\triangle N p 63 \alpha$-regulated genes there was also one gene encoding miRNA, miR-205, which is a known target of p63 in bladder [45] and prostate carcinomas [46] and which was shown to be down-regulated in TNBC [47] and suggested to play a tumour suppressor role in TNBC cells [48].

\section{$\triangle \mathrm{Np63a}$ induces loss of adhesion and detachment of MDA-MB-468 cells}

Since $\Delta \mathrm{Np} 63 \alpha$ changed expression of adhesion-related genes, we analysed adhesion of MDA-MB-468- $\Delta \mathrm{Np} 63 \alpha$, MDA-MB-468-TAp63 $\alpha$ and MDA-MB-468-pcDNA6/TR cells with and without tetracycline treatment. xCELLigence real-time cell analysis showed that cell-index values, which reflect the coverage of electrodes by cells, were significantly decreased after tetracycline treatment of MDA-MB-468- $\Delta$ Np63 $\alpha$ and MDA-MB-468-TAp63 $\alpha$ cells (Fig. 3a). Cell-index started to decrease approximately $9 \mathrm{~h}$ after addition of tetracycline and the impact of $\Delta \mathrm{Np} 63 \alpha$ was much higher compared to TAp63 $\alpha$. Tetracycline itself did not influence the cell-index (Fig. 3a).

This result was confirmed by detachment assay which measures cell adhesion based on cell sensitivity to trypsin [49] (Fig. 3b). Absorbance measured was dependent on the number of cells that remained adherent after trypsinization and thus correlated with cell adhesion. We observed strong decrease of absorbance after induction of $\Delta \mathrm{Np} 63 \alpha$ and a smaller decrease after TAp63 $\alpha$ induction (Fig. 3b).

To confirm these data, we also used transient expression in another basal-A cell line, BT-20 and in a basal-B (mesenchymal) TNBC cell line, BT-549. Similar effects of $\Delta N p 63 \alpha$ on cell adhesion/proliferation were observed when BT-20 cells were transiently transfected with $\Delta \mathrm{Np} 63 \alpha$ and cell index was measured by xCELLigence (Fig. 4). On the contrary, transient transfection of BT-549 did not significantly influence cell behaviour. These results suggest that $\Delta \mathrm{Np} 63 \alpha$ effect is not restricted to one cell line but depends on different molecular backgrounds.

\section{$\Delta$ Np63a-mediated loss of cell adhesion is accompanied by cell cycle arrest and reduced proliferation rate in vitro and in vivo}

To investigate the effect of p63 isoforms on proliferation and viability of MDA-MB-468- $\triangle \mathrm{Np} 63 \alpha$ and MDA-MB468-TAp63 $\alpha$ cells, we detected their proliferation rate, propidium iodide (PI) exclusion and cell cycle regulation after tetracycline treatment. Adhesion and proliferation of MDA-MB-468- $\triangle$ Np63 $\alpha$ were significantly decreased 48 


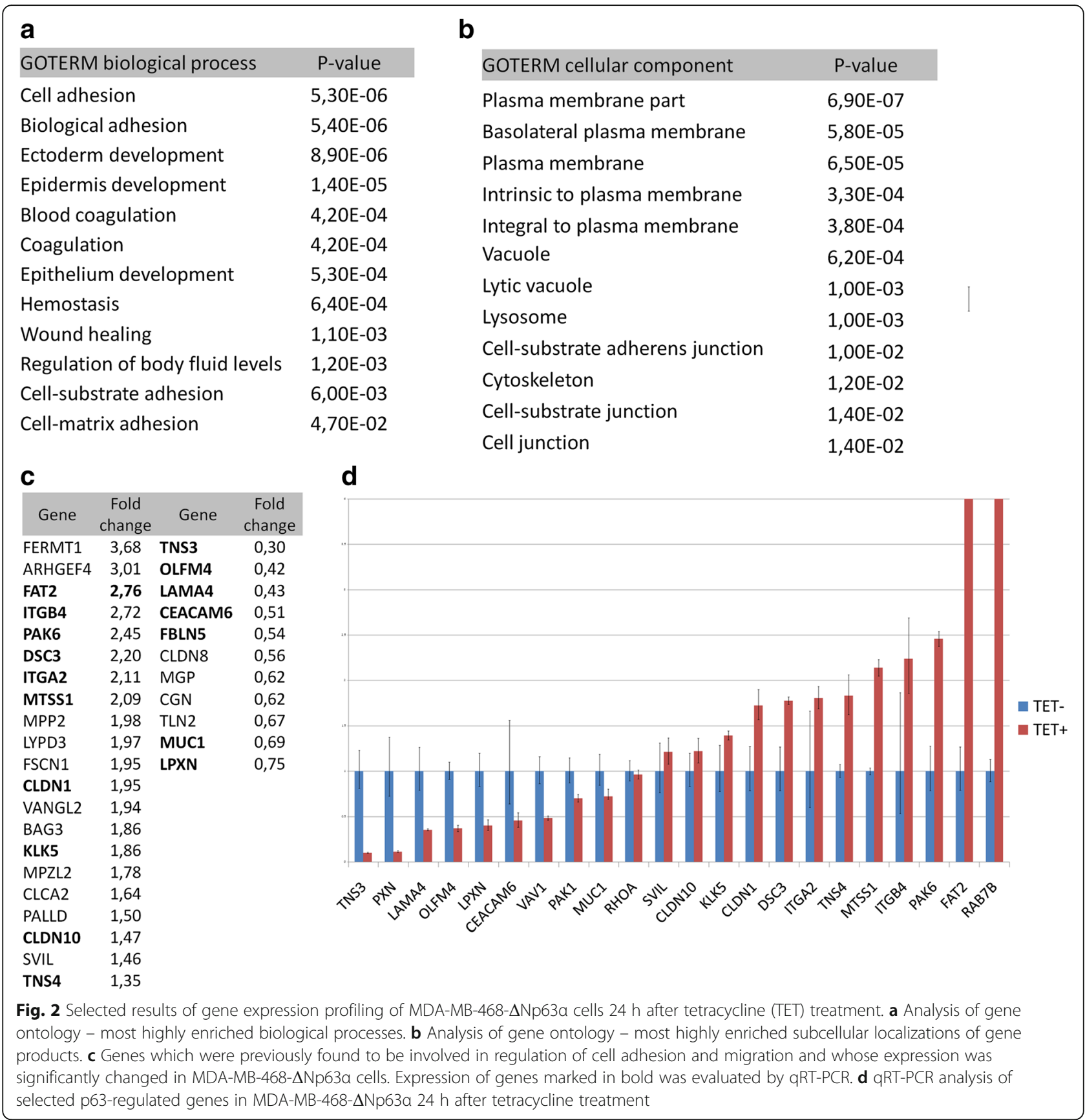

and $72 \mathrm{~h}$ after tetracycline treatment compared to control cells, the effect of TAp63 $\alpha$ was only weak (Fig. 5a, b).

According to PI exclusion assay, cell viability of MDAMB-468- $\Delta$ Np63 $\alpha$ cells was not affected 24 and $48 \mathrm{~h}$ after tetracycline treatment, but the cells started to die $72 \mathrm{~h}$ after tetracycline treatment (Fig. $5 \mathrm{c}$, increased number of PI positive cells, $p<0.05, t$-test). Decreased proliferation of MDA-MB-468- $\Delta$ Np63 $\alpha$ cells was accompanied by cell cycle arrest (Fig. 5d). To see whether these antiproliferative effects of $\Delta \mathrm{Np} 63 \alpha$ expression are detectable also in vivo in more natural tumour environment, MDA-
MB-468- $\Delta$ Np63 $\alpha$ cells were subcutaneously injected into SCID mice. MDA-MB-468- $\Delta$ Np63 $\alpha$ injected mice showed a significant decrease in tumour size after tetracycline treatment ( $p<0.001, t$-test) compared to the corresponding controls (Fig. $6 \mathrm{a}, \mathrm{b}$ ). Induction of $\Delta \mathrm{Np} 63 \alpha$ expression in MDA-MB-468 xenografts was confirmed by SDSPAGE and western blot (Fig. 6c). Moreover, GADD45A and $C D K N 1 A$ growth arrest-related genes were upregulated after $\Delta \mathrm{Np} 63 \alpha$ induction (Additional file 3). Because MDA-MB-468 cells are non-metastatic in xenografts [50], we cannot comment on whether p63 influenced this 

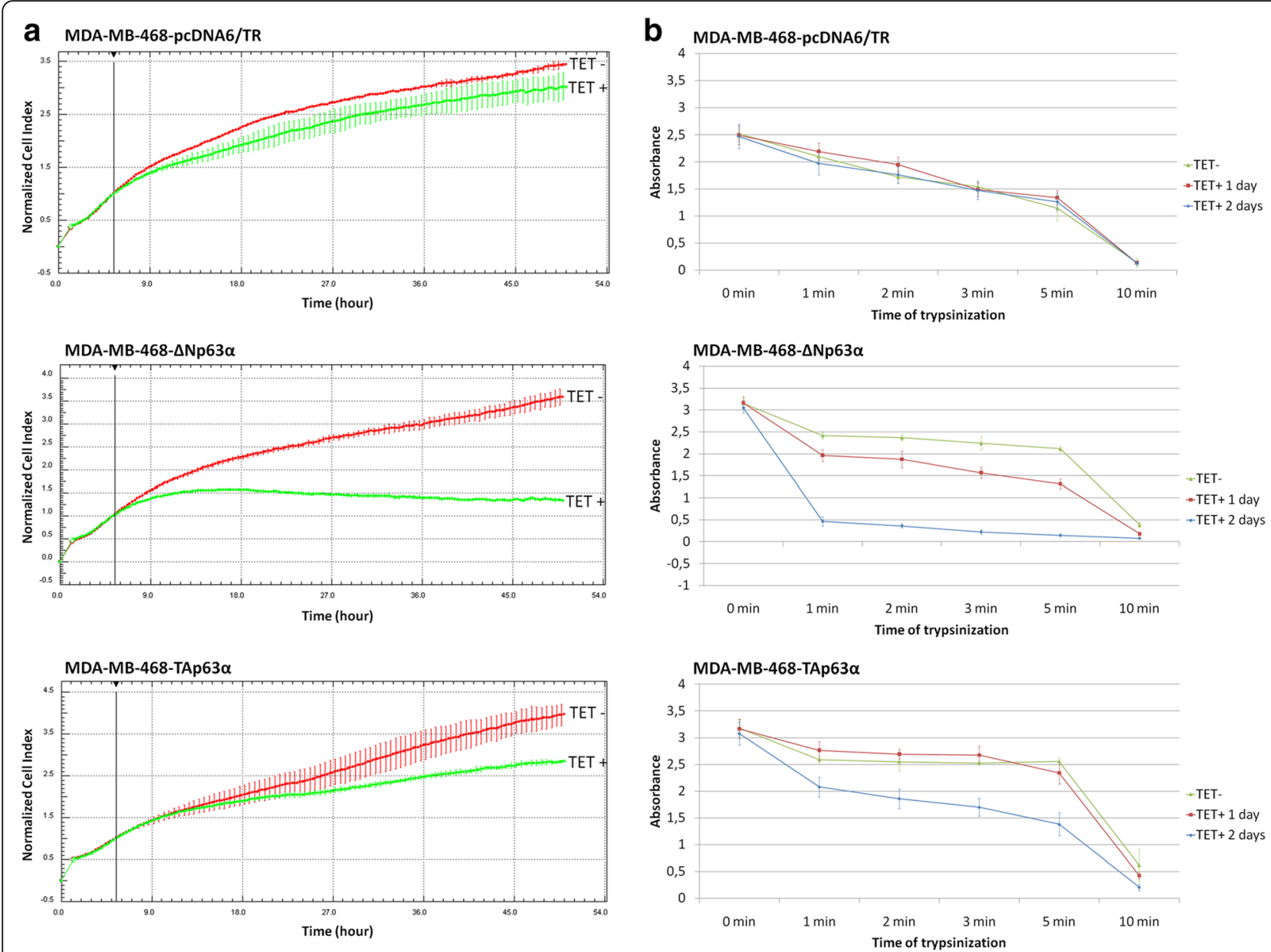

Fig. 3 Analysis of MDA-MB-468- $\triangle$ Np63a, MDA-MB-468-TAp63a and MDA-MB-468-pcDNA6/TR cell adhesion with xCELLigence system and detachment assay. $\mathbf{a}$ XCELLigence real-time cell analysis; tetracycline was added at the beginning of the experiment (time 0 ), decrease in cell index correlated with cell detachment; b detachment assay; decrease in absorbance correlated with cell sensitivity to trypsin and reduced cell adhesion
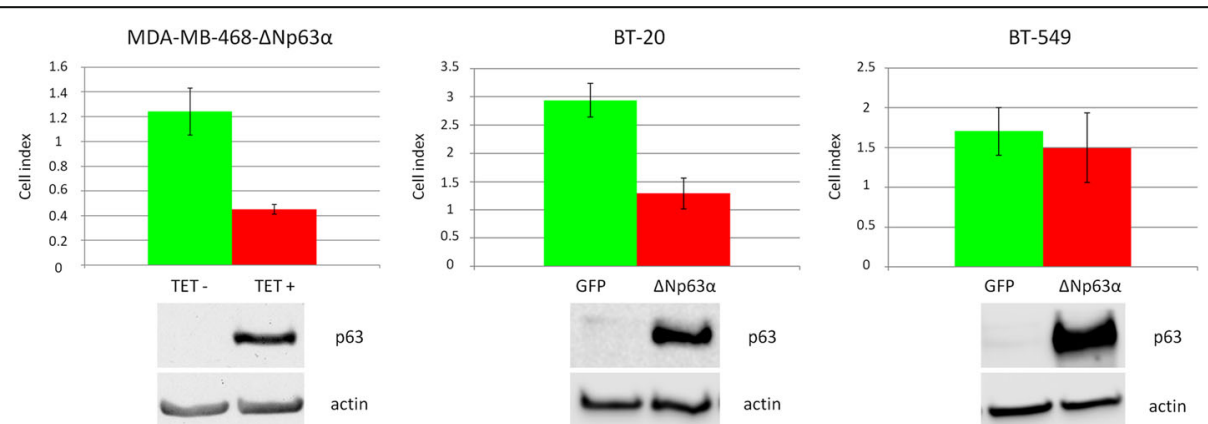

Fig. 4 Different effects of $\Delta N p 63 a$ on cell adhesion/proliferation in BT-20 and BT-549 cells. BT-20 and BT-549 cells were transiently transfected with pcDNA3- $\Delta$ Np63a and pcDNA3-GFP plasmids and analyzed by xCELLigence $24 \mathrm{~h}$ after transfection. Cell index was significantly decreased in BT-20 cells expressing $\Delta$ Np63a $(p<0.01, t$-test) and MDA-MB-468- $\Delta$ Np63a cells treated with tetracycline $(p<0.01, t$-test) but not in BT-549 cells expressing $\Delta \operatorname{Np63a}(p=0.15, t$-test) after $48 \mathrm{~h}$. Expression of $\Delta$ Np63a $24 \mathrm{~h}$ after transfection / tetracycline treatment was confirmed by western blot 


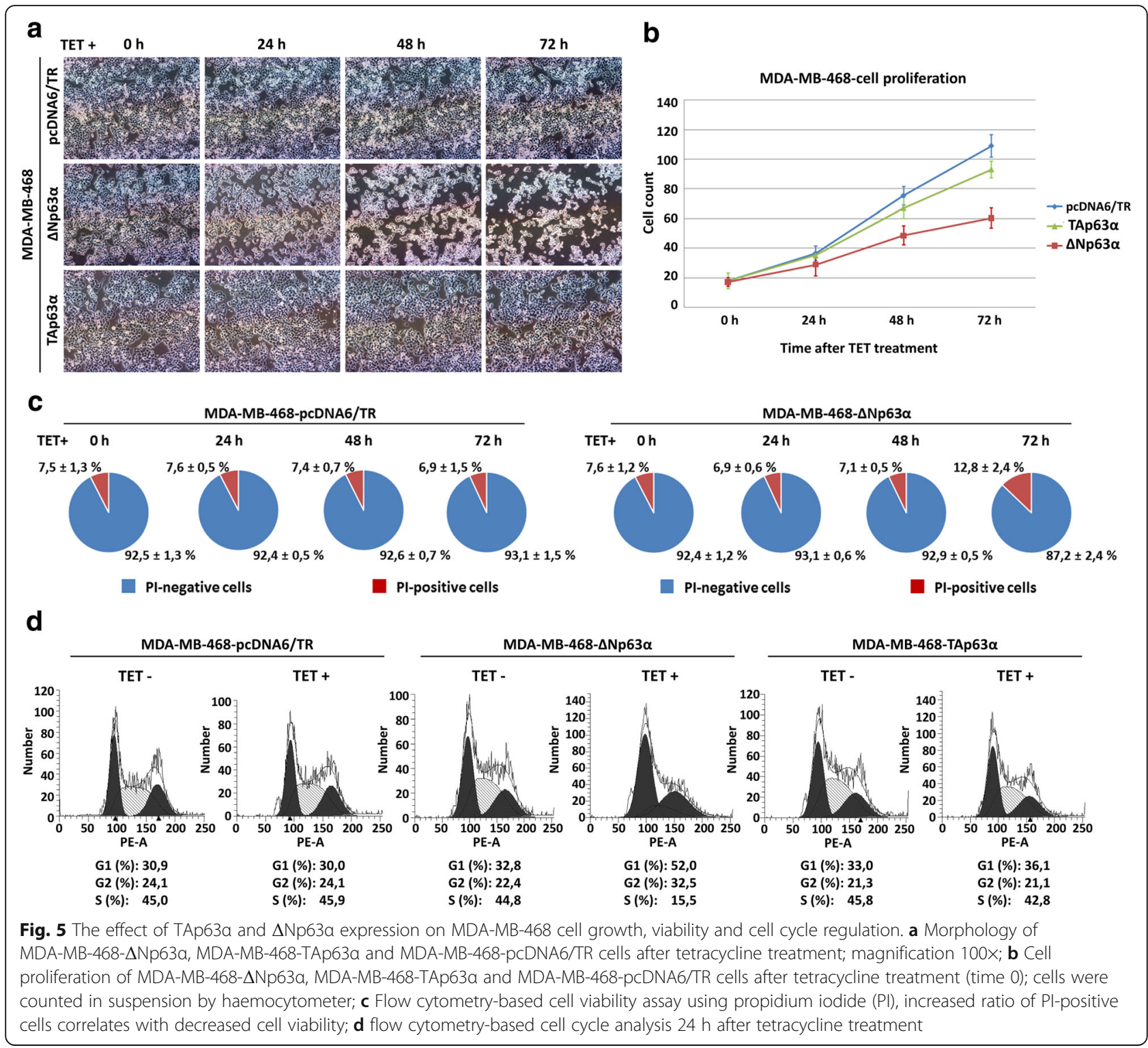

process, although there was no evidence of local invasion or overt distant metastasis in any group of mice.

Transwell migration assay with xCELLigence CIM plates and wound-healing assay were employed to study the effect of $\Delta \mathrm{Np} 63 \alpha$ on cell migration and invasion. MDA-MB-468 cells have very low migratory and invasive activity in vitro $[38,51]$ and transwell migration of these cells was not measurable. Wound-healing assay did not show any changes in cell migration after $20 \mathrm{~h}$ and evaluation of results after longer time was not possible due to changes in proliferation and cell detachment (Fig. 6d).

To compare resistance of MDA-MB-468 cells to anoikis, cells were grown in suspension on bacterial plates that did not allow them to adhere. Their viability was measured using PI exclusion assay after 24, 48 and $72 \mathrm{~h}$. We did not found any apparent correlation between $\Delta \mathrm{Np} 63 \alpha$ expression and resistance to anoikis (Additional file 4).

\section{Discussion}

TNBC is an aggressive form of breast cancer with shorter median time to relapse and death compared to other breast cancer subtypes, so there is an urgent need to expand our knowledge of TNBC biology and molecular mechanisms involved in tumour progression and metastasis [52]. p63 expression was previously detected in a group of breast tumours with triple-negative phenotype and basal-like epithelial features and the $\Delta \mathrm{Np} 63 /$ TAp73 ratio shown to correlate with sensitivity to cisplatin treatment in vitro [23] as well as in TNBC patients [53]. To gain a deeper insight into the function of p63 in TNBC cells, we have created stably transfected 
a

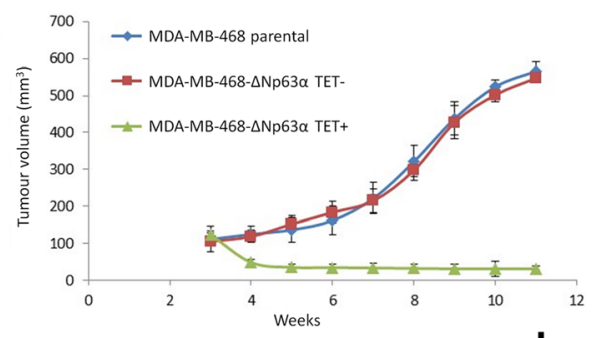

C

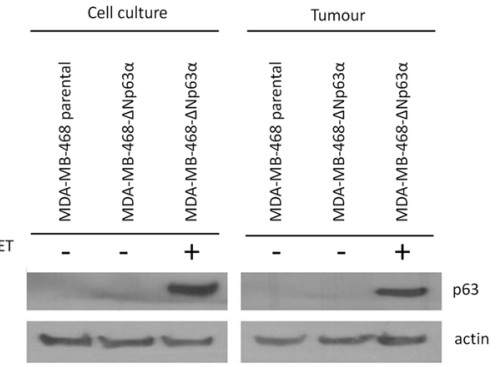

d b
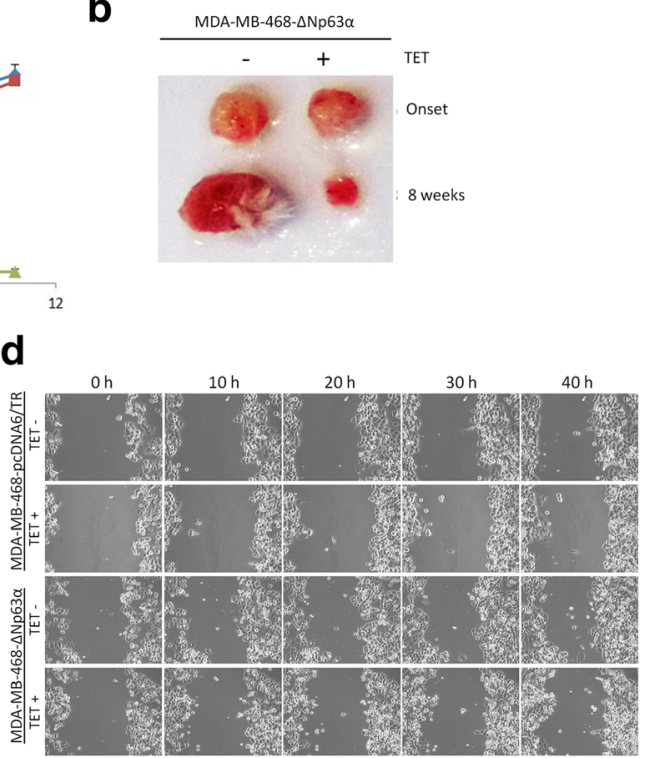

Fig. 6 Induction of $\triangle$ Np63a in MDA-MB-468 cells reduces tumour size in vivo and does not change cell migration. a Growth rates of MDA-MB468- $\Delta$ Np63a tumour xenografts in SCID mice (bars indicate standard deviation of tumour volumes, $n=6$ sites injected); $\mathbf{b}$ representative images of tumours excised on tumour onset and after 8 weeks of $\Delta$ Np63a induction (experimental endpoint); $\mathbf{c}$ detection of p63 protein level in tumour lysates, protein extracts from corresponding cell cultures were used as controls; $\mathbf{d}$ representative images of wound-healing assay, tetracycline was added at the beginning of the experiment (time 0)

MDA-MB-468 cell lines with inducible expression of $\Delta \mathrm{Np} 63 \alpha$ and TAp63 $\alpha$. MDA-MB-468 cells have a triplenegative phenotype and belong to the basal-A group of TNBC [39]. They show also several typical features of TNBC including mutated TP53, mutated PTEN and EGFR overexpression [54].

Although we could see similar levels of $\Delta \mathrm{Np} 63 \alpha$ and TAp63 $\alpha$ induction at both the mRNA and protein levels, genome-wide expression profiling showed that only $\Delta \mathrm{Np} 63 \alpha$ has a significant impact on changes in gene expression. This is contrary to the initial assumptions that TAp63 is more active in transactivation of target genes compared to $\Delta \mathrm{N}$ isoforms [1] and acts to induce apoptosis, growth arrest, and luminal differentiation in mammary epithelium [20, 55]. However, we and others have shown that $\Delta \mathrm{Np} 63$ is the predominant isoform in adult epithelial tissues, including basal breast cells and basal-type breast cancers $[4,5,28]$. This latter paper also showed a negligible effect of TAp63 expression in breast epithelial cells, compared to a pro-tumorigenic role for $\Delta \mathrm{Np} 63$. The list of genes whose expression changed after $\Delta \mathrm{Np} 63 \alpha$ induction included many known target genes of p63 (see Results and Additional file 3), thus confirming the validity of our results [56-59].

Gene ontology analysis showed that $\Delta \mathrm{Np} 63 \alpha$ controls genes involved in regulating cell adhesion. Until recently, p63 was usually mentioned in connection with maintenance of basal and progenitor/stem cell phenotype in breast cancer cells or with cell survival and DNA damage responses $[13,20,21,28]$. However, it has been previously demonstrated that p63 isoforms can regulate cell adhesion and related processes such as cell migration and invasion in different cancer types. p63 was shown to regulate adhesion and migration-related genes in head and neck squamous cell carcinoma cells and also in other squamous cell and urothelial carcinomas [60-62]. Moreover, knockdown of p63 caused down-regulation of cell adhesionassociated genes, cell detachment and anoikis in nontransformed mammary epithelial cells and keratinocytes [63]. CD44, a cell surface glycoprotein that regulates cell adhesion and migration and is connected to stem cell phenotype in different tumour types including breast cancer, was shown to be a direct $\Delta \mathrm{Np} 63$ transcriptional target [64]. Most importantly, Cheung et al. have shown that invasion of breast tumours is led by a subpopulation of cells that are defined by their expression of basal epithelial genes including cytokeratin 14 (K14) and p63 [65]. Interestingly, although usually only a minority of cells within breast tumours expressed basal epithelial genes, knockdown of either K14 or p63 was sufficient to block collective invasion in primary tumour organoids. Although p63 is a transcriptional activator of K14, the authors suggested that p63 has K14-independent function in collective invasion. As changes in cell adhesion are an important event in the process of invasion and metastasis, we hypothesise that changes in expression of genes involved in regulation of cell adhesion that we have shown here could be a mechanism by which p63 influences cell invasion. 
We recently reported results of CRISPR/Cas9-mediated TP63 knock-out in the HCC1806 basal-A breast cancer cell line [29]. The major findings from this model were related to alterations of differentiation markers, where p63 is required to suppress expression of luminal markers and maintain the basal epithelial phenotype, but p63 loss is insufficient to induce full luminal-type differentiation. We also found that p63 depletion changed expression of adhesion molecules in a similar manner to that observed here, with reciprocal changes in FAT2, ITGA2, CLDN1, LAMA4 and CEACAM6 following p63 depletion [29] or p63 induction (this manuscript). However, either over-expression or gene knockout each caused a loss of cellular adhesion in the respective cell lines, indicating that the consequences of manipulating p63 levels are dependent on the cells under investigation, which likely relates to their dependence on p63 and their different genetic backgrounds.

The results of gene expression profiling were used to investigate cell phenotype, where induction of $\Delta \mathrm{Np} 63 \alpha$ caused visible loss of MDA-MB-468 cell adhesion and eventual cell detachment. Loss of cell adhesion was accompanied by decreased proliferation and cell cycle arrest and cell detachment caused decreased cell viability after 3 days of $\Delta \mathrm{Np} 63 \alpha$ induction. The same effect was observed in vivo in SCID mice, where induction of $\Delta \mathrm{Np} 63 \alpha$ correlated with decreased tumour size. This is contrary to the often reported importance of $\Delta \mathrm{Np} 63$ for maintenance of cell proliferation [66-68] suggesting that p63 has a complex role in regulation of tumour cell fate. However, it is in agreement with previously reported ability of $\Delta \mathrm{Np} 63 \alpha$ to induce cell cycle arrest and upregulate GADD45 and CDKN1A genes [69]. Similar data for the effects of $\triangle \mathrm{Np} 63 \alpha$ on proliferation and adhesion were seen in another basal-A (epithelial) type cell line, BT-20. Interestingly, these effects were not seen in basal-B (mesenchymal) type TNBC BT-549 cells, suggesting that $\Delta \mathrm{Np} 63 \alpha$ has cell context specific effects that relate to epithelial/ mesenchymal cell phenotypes. This notion will require further investigation, but mirrors the expression pattern of p63 in primary human breast cancers, where p63 is a defining characteristic of basal-A TNBCs and basal-B mesenchymal-type TNBCs do not express p63 [38, 39].

\section{Conclusions}

In summary, we have produced MDA-MB-468 basal-type breast cancer cells with inducible p63 expression vectors. Although most of our data are derived only from this cell line, we show that $\Delta \mathrm{Np} 63 \alpha$ had much stronger effects on gene expression than TAp63 $\alpha$, questioning whether this isoform has a physiological role in basal-type breast cancer. Further studies using other cell lines will be required to assess the generality of the findings and may indeed reveal further cell-context-dependent effects of p63 in cancer. In addition, correlations between p63 and the adhesion-related processes will be required in clinical samples to understand the potential role of p63 on patient outcome in basal-type breast cancer. In this respect, although p63 is usually mentioned mostly in connection with basal phenotype and stem cells in normal breast tissue and breast cancer, we showed that a major effect of p63 in MDA-MB-468 cells is regulation of cell adhesion, a process important in metastasis and invasion of tumour cells. We also found that $\Delta \mathrm{Np} 63 \alpha$ can inhibit cell proliferation in vitro and suppress tumour growth in vivo suggesting context-dependent effects of p63 in cancer.

\section{Additional files}

Additional file 1: List of primers used for qRT-PCR. (PDF $266 \mathrm{~kb}$ )

Additional file 2: Expression of TP63 in breast cancer cell lines. (PDF 407 $\mathrm{kb})$

Additional file 1: List of primers used for qRT-PCR.

Additional file 2: Expression of TP63 in breast cancer cell lines.

Additional file 3: List of genes whose expression was changed $24 \mathrm{~h}$ after induction of $\triangle N p 63 a$ or TAp63a expression in MDA-MB-468 cells. (PDF 503 kb)

Additional file 4: Measurement of anoikis resistance of MDA-MB-468$\triangle$ Np63a cells. (PDF $249 \mathrm{~kb}$ )

\section{Abbreviations}

CSC: Cancer stem cells; ER: Estrogen receptor; HER2: Human epidermal growth factor receptor 2; PR: Progesterone receptor; TET: Tetracycline; TNBC: Triple-negative breast carcinoma

\section{Acknowledgements}

Not applicable.

\section{Funding}

The work was supported by IGA NT/14602-3/2013, GACR P206/12/G151 (JH, PJC and BV), MH CZ - DRO (MMCI, 00209805) and the project MEYS - NPS I - LO1413. XG and KN were supported by Swedish Cancer Society Contract number 140752.

\section{Availability of data and materials}

The datasets generated during and/or analysed during the current study are available in the ArrayExpress repository, https://www.ebi.ac.uk/arrayexpress/ experiments/E-MTAB-3761.

\section{Authors' contributions}

MN prepared stably transfected cell lines, carried out the tissue culture experiments, participated in transcription profiling and drafted the manuscript. JH prepared vectors and helped with tissue culture experiments and helped to draft the manuscript. XG and KN carried out the transcription profiling and data analysis. VH and PO participated in qRT-PCR experiments. SG, SL and VZ carried out the mouse xenografts. YL helped with tissue culture and flow-cytometry experiments. PC and BV helped with data interpretation, participated in drafting the manuscript and critical revision. All authors have read and approved the final manuscript.

\section{Competing interests}

The authors declare that they have no competing interests.

Consent for publication

Not applicable.

Ethics approval and consent to participate

All experiments with mice were performed in the authorized animal house of the National Hellenic Research Foundation. Experiments complied with 
the Protocol on the Protection and Welfare of Animals, as obliged by the rules of the National Hellenic Research Foundation, the regulations of the National Bioethics Committee and article 3 of the presidential decree 160/ 1991 (in line with 86/609/EEC directive) regarding the protection of experimental animals. The animal studies were approved by the NHRF Bioethics Committee (application 2014/07/15, approval 2014/07/28).

\section{Author details}

${ }^{1}$ Regional Centre for Applied Molecular Oncology, Masaryk Memorial Cancer Institute, Zluty kopec 7, Brno 65653, Czech Republic. ²Department of Medical Biosciences, Umeå University, Umeå 90185, Sweden. ${ }^{3}$ Institute of Biology, Medicinal Chemistry \& Biotechnology, NHRF, Athens, Greece. ${ }^{4}$ NCRC, 026-329S, University of Michigan, Ann Arbor, Ml 48109, USA.

\section{Received: 1 November 2015 Accepted: 23 September 2016} Published online: 10 October 2016

\section{References}

1. Yang A, Kaghad M, Wang Y, Gillett E, Fleming MD, Dotsch V, Andrews NC, et al. p63, a p53 homolog at 3q27-29, encodes multiple products with transactivating, death-inducing, and dominant-negative activities. Mol Cell. 1998:2:305-16.

2. Ghioni P, Bolognese F, Duijf PH, Van Bokhoven H, Mantovani R, Guerrini L. Complex transcriptional effects of p63 isoforms: identification of novel activation and repression domains. Mol Cellular Biol. 2002;22:8659-68.

3. Helton ES, Zhu J, Chen X. The unique NH2-terminally deleted (DeltaN) residues, the PXXP motif, and the PPXY motif are required for the transcriptional activity of the DeltaN variant of p63. J Biol Chem. 2006;281:2533-42.

4. Nekulova M, Holcakova J, Nenutil R, Stratmann R, Bouchalova P, Muller P, Moukova L, et al. Characterization of specific p63 and p63-N-terminal isoform antibodies and their application for immunohistochemistry. Virchows Arch. 2013;463:415-25.

5. Nylander K, Vojtesek B, Nenutil R, Lindgren B, Roos G, Zhanxiang W, Sjostrom B, et al. Differential expression of p63 isoforms in normal tissues and neoplastic cells. J Pathol. 2002;198:417-27.

6. Humphries LA, Godbersen JC, Danilova OV, Kaur P, Christensen BC, Danilov AV. Pro-apoptotic TP53 homolog TAp63 is repressed via epigenetic silencing and B-cell receptor signalling in chronic lymphocytic leukaemia. $\mathrm{Br}$ J Haematol. 2013;163:590-602.

7. Suh EK, Yang A, Kettenbach A, Bamberger C, Michaelis AH, Zhu Z, Elvin JA, et al. p63 protects the female germ line during meiotic arrest. Nature. 2006; 444:624-8.

8. Hibi K, Trink B, Patturajan M, Westra WH, Caballero OL, Hill DE, Ratovitski EA, et al. AIS is an oncogene amplified in squamous cell carcinoma. Proc Natl Acad Sci USA. 2000;97:5462-7.

9. Orzol P, Holcakova J, Nekulova M, Nenutil R, Vojtesek B, Coates PJ. The diverse oncogenic and tumour suppressor roles of p63 and p73 in cancer: a review by cancer site. Histol Histopathol. 2015;30:503-21.

10. Barbareschi M, Pecciarini L, Cangi MG, Macri E, Rizzo A, Viale G, Doglioni C. p63, a p53 homologue, is a selective nuclear marker of myoepithelial cells of the human breast. Am J Surg Pathol. 2001;25:1054-60.

11. Batistatou A, Stefanou D, Arkoumani $E_{1}$ Agnantis NJ. The usefulness of p63 as a marker of breast myoepithelial cells. In Vivo. 2003;17:573-6.

12. Yang A, Schweitzer $R$, Sun D, Kaghad M, Walker N, Bronson RT, Tabin C, et al. p63 is essential for regenerative proliferation in limb, craniofacial and epithelial development. Nature. 1999;398:714-8.

13. Yalcin-Ozuysal O, Fiche M, Guitierrez M, Wagner KU, Raffoul W, Brisken C. Antagonistic roles of Notch and p63 in controlling mammary epithelial cell fates. Cell Death Differ. 2010;17:1600-12.

14. Forster N, Saladi SV, van Bragt M, Sfondouris ME, Jones FE, Li Z, Ellisen LW. Basal cell signaling by p63 controls luminal progenitor function and lactation via NRG1. Dev Cell. 2014;28:147-60.

15. Yallowitz AR, Alexandrova EM, Talos F, Xu S, Marchenko ND, Moll UM. p63 is a prosurvival factor in the adult mammary gland during post-lactational involution, affecting PI-MECs and ErbB2 tumorigenesis. Cell Death Differ 2014;21:645-54.

16. Petersen OW, Polyak K. Stem cells in the human breast. Cold Spring Harbor Perspect Biol. 2010;2:a003160.

17. Bai L, Rohrschneider LR. s-SHIP promoter expression marks activated stem cells in developing mouse mammary tissue. Genes Dev. 2010;24:1882-92.
18. Deugnier MA, Faraldo MM, Teuliere J, Thiery JP, Medina D, Glukhova MA. Isolation of mouse mammary epithelial progenitor cells with basal characteristics from the Comma-Dbeta cell line. Dev Biol. 2006;293:414-25.

19. Thomas E, Zeps N, Cregan M, Hartmann P, Martin T. 14-3-3sigma (sigma) regulates proliferation and differentiation of multipotent p63-positive cells isolated from human breastmilk. Cell Cycle. 2011;10:278-84.

20. Li N, Singh S, Cherukuri P, Li H, Yuan Z, Ellisen LW, Wang B, et al. Reciprocal intraepithelial interactions between TP63 and hedgehog signaling regulate quiescence and activation of progenitor elaboration by mammary stem cells. Stem Cells. 2008;26:1253-64.

21. Du Z, Li J, Wang L, Bian C, Wang Q, Liao L, Dou X, et al. Overexpression of DeltaNp63alpha induces a stem cell phenotype in MCF7 breast carcinoma cell line through the Notch pathway. Cancer Sci. 2010;101:2417-24.

22. Koker MM, Kleer CG. p63 expression in breast cancer: a highly sensitive and specific marker of metaplastic carcinoma. Am J Surg Pathol. 2004;28:1506-12.

23. Leong CO, Vidnovic N, DeYoung MP, Sgroi D, Ellisen LW. The p63/p73 network mediates chemosensitivity to cisplatin in a biologically defined subset of primary breast cancers. J Clin Invest. 2007;117:1370-80.

24. Reis-Filho JS, Milanezi F, Steele D, Savage K, Simpson PT, Nesland JM, Pereira EM, et al. Metaplastic breast carcinomas are basal-like tumours. Histopathology. 2006:49:10-21.

25. Carey LA, Dees EC, Sawyer L, Gatti L, Moore DT, Collichio F, Ollila DW, et al. The triple negative paradox: primary tumor chemosensitivity of breast cancer subtypes. Clin Can Res. 2007;13:2329-34.

26. Dent R, Trudeau M, Pritchard KI, Hanna WM, Kahn HK, Sawka CA, Lickley LA, et al. Triple-negative breast cancer: clinical features and patterns of recurrence. Clin Can Res. 2007;13:4429-34.

27. Crown J, O'Shaughnessy J, Gullo G. Emerging targeted therapies in triplenegative breast cancer. Ann Oncol. 2012;23 Suppl 6:vi56-65.

28. Chakrabarti R, Wei Y, Hwang J, Hang X, Andres Blanco M, Choudhury A, Tiede $B$, et al. DeltaNp63 promotes stem cell activity in mammary gland development and basal-like breast cancer by enhancing Fzd7 expression and Wnt signalling. Nature Cell Biol. 2014;16:1004-15. 1-13.

29. Orzol P, Nekulova M, Holcakova J, Muller P, Votesek B, Coates PJ. DeltaNp63 regulates cell proliferation, differentiation, adhesion, and migration in the BL2 subtype of basal-like breast cancer. Tumor Biol. 2016. doi:10.1007/ s13277-016-4880-x.

30. Buckley NE, Conlon SJ, Jirstrom K, Kay EW, Crawford NT, O'Grady A, Sheehan $\mathrm{K}$, et al. The DeltaNp63 proteins are key allies of BRCA1 in the prevention of basal-like breast cancer. Cancer Res. 2011;71:1933-44.

31. Craig AL, Holcakova J, Finlan LE, Nekulova M, Hrstka R, Gueven N, DiRenzo J, et al. DeltaNp63 transcriptionally regulates ATM to control p53 Serine-15 phosphorylation. Mol Cancer. 2010;9:195.

32. Lin YL, Sengupta S, Gurdziel K, Bell GW, Jacks T, Flores ER. p63 and p73 transcriptionally regulate genes involved in DNA repair. PLoS Genet. 2009;5, e1000680.

33. Flores ER, Sengupta S, Miller JB, Newman JJ, Bronson R, Crowley D, Yang A, et al. Tumor predisposition in mice mutant for p63 and p73: evidence for broader tumor suppressor functions for the p53 family. Cancer Cell. 2005;7:363-73.

34. Adorno M, Cordenonsi M, Montagner M, Dupont S, Wong C, Hann B, Solari A, et al. A Mutant-p53/Smad complex opposes p63 to empower TGFbetainduced metastasis. Cell. 2009;137:87-98.

35. Ritchie ME, Phipson B, Wu D, Hu YF, Law CW, Shi W, Smyth GK. Limma powers differential expression analyses for RNA-sequencing and microarray studies. Nucleic Acids Res. 2015:43:13.

36. Saeed Al, Sharov V, White J, Li J, Liang W, Bhagabati N, Braisted J, et al. TM4: A free, open-source system for microarray data management and analysis. Biotechniques. 2003;34:374-8.

37. Huang DW, Sherman BT, Lempicki RA. Systematic and integrative analysis of large gene lists using DAVID bioinformatics resources. Nat Protoc. 2009;4: 44-57.

38. Neve RM, Chin K, Fridlyand J, Yeh J, Baehner FL, Fevr T, Clark L, et al. A collection of breast cancer cell lines for the study of functionally distinct cancer subtypes. Cancer Cell. 2006;10:515-27.

39. Lehmann BD, Bauer JA, Chen $X$, Sanders ME, Chakravarthy AB, Shyr $Y$, Pietenpol JA. Identification of human triple-negative breast cancer subtypes and preclinical models for selection of targeted therapies. J Clin Invest. 2011:121:2750-67.

40. Xu L, Yin S, Banerjee S, Sarkar F, Reddy KB. Enhanced anticancer effect of the combination of cisplatin and TRAIL in triple-negative breast tumor cells. Mol Cancer Ther. 2011;10:550-7. 
41. Barretina J, Caponigro G, Stransky N, Venkatesan K, Margolin AA, Kim S, Wilson CJ, et al. The Cancer Cell Line Encyclopedia enables predictive modelling of anticancer drug sensitivity. Nature. 2012;483:603-7.

42. Klijn C, Durinck S, Stawiski EW, Haverty PM, Jiang Z, Liu H, Degenhardt J, et al. A comprehensive transcriptional portrait of human cancer cell lines. Nat Biotechnol. 2015:33:306-12.

43. Lim LY, Vidnovic N, Ellisen LW, Leong CO. Mutant p53 mediates survival of breast cancer cells. Br J Cancer. 2009;101:1606-12.

44. Katz M, Amit I, Citri A, Shay T, Carvalho S, Lavi S, Milanezi F, et al. A reciprocal tensin-3-cten switch mediates EGF-driven mammary cell migration. Nature Cell Biol. 2007;9:961-9.

45. Tran MN, Choi W, Wszolek MF, Navai N, Lee IL, Nitti G, Wen S, et al. The p63 protein isoform DeltaNp63alpha inhibits epithelial-mesenchymal transition in human bladder cancer cells: role of MIR-205. J Biol Chem. 2013;288:327588.

46. Tucci P, Agostini M, Grespi F, Markert EK, Terrinoni A, Vousden KH, Muller PA, et al. Loss of p63 and its microRNA-205 target results in enhanced cell migration and metastasis in prostate cancer. Proc Natl Acad Sci USA. 2012; 109:15312-7.

47. Radojicic J, Zaravinos A, Vrekoussis T, Kafousi M, Spandidos DA, Stathopoulos EN. MicroRNA expression analysis in triple-negative (ER, PR and Her2/neu) breast cancer. Cell Cycle. 2011;10:507-17.

48. Piovan C, Palmieri D, Di Leva G, Braccioli L, Casalini P, Nuovo G, Tortoreto M, et al. Oncosuppressive role of p53-induced miR-205 in triple negative breast cancer. Mol Oncol. 2012;6:458-72.

49. Barras D, Lorusso G, Ruegg C, Widmann C. Inhibition of cell migration and invasion mediated by the TAT-RasGAP317-326 peptide requires the DLC1 tumor suppressor. Oncogene. 2014;33:5163-72.

50. Vantyghem SA, Allan AL, Postenka CO, Al-Katib W, Keeney M, Tuck AB, Chambers AF. A new model for lymphatic metastasis: development of a variant of the MDA-MB-468 human breast cancer cell line that aggressively metastasizes to lymph nodes. Clin Exp Metastasis. 2005;22:351-61.

51. Sommers CL, Byers SW, Thompson EW, Torri JA, Gelmann EP. Differentiation state and invasiveness of human breast cancer cell lines. Breast Cancer Res Treat. 1994;31:325-35.

52. Hudis CA, Gianni L. Triple-negative breast cancer: an unmet medical need. Oncologist. 2011;16 Suppl 1:1-11.

53. Silver DP, Richardson AL, Eklund AC, Wang ZC, Szallasi Z, Li Q, Juul N, et al. Efficacy of neoadjuvant Cisplatin in triple-negative breast cancer. J Clin Oncol. 2010;28:1145-53.

54. She QB, Chandarlapaty S, Ye Q, Lobo J, Haskell KM, Leander KR, DeFeoJones $\mathrm{D}$, et al. Breast tumor cells with PI3K mutation or HER2 amplification are selectively addicted to Akt signaling. PloS One. 2008;3, e3065.

55. Gressner O, Schilling T, Lorenz K, Schulze Schleithoff E, Koch A, SchulzeBergkamen $\mathrm{H}$, Lena AM, et al. TAp63alpha induces apoptosis by activating signaling via death receptors and mitochondria. EMBO J. 2005;24:2458-71.

56. Lapi E, lovino A, Fontemaggi G, Soliera AR, lacovelli S, Sacchi A, Rechavi G, et al. S100A2 gene is a direct transcriptional target of p53 homologues during keratinocyte differentiation. Oncogene. 2006;25:3628-37.

57. Sasaki Y, Koyama R, Maruyama R, Hirano T, Tamura M, Sugisaka J, Suzuki H, et al. CLCA2, a target of the p53 family, negatively regulates cancer cell migration and invasion. Cancer Biol Ther. 2012;13:1512-21.

58. Sen GL, Boxer LD, Webster DE, Bussat RT, Qu K, Zarnegar BJ, Johnston D, et al. ZNF750 is a p63 target gene that induces KLF4 to drive terminal epidermal differentiation. Dev Cell. 2012;22:669-77.

59. Yan W, Chen X. GPX2, a direct target of p63, inhibits oxidative stressinduced apoptosis in a p53-dependent manner. J Biol Chem. 2006;281: 7856-62.

60. Barbieri CE, Tang LJ, Brown KA, Pietenpol JA. Loss of p63 leads to increased cell migration and up-regulation of genes involved in invasion and metastasis. Cancer Res. 2006;66:7589-97.

61. Fukushima H, Koga F, Kawakami S, Fuji Y, Yoshida S, Ratovitski E, Trink B, et al. Loss of DeltaNp63alpha promotes invasion of urothelial carcinomas via N-cadherin/Src homology and collagen/extracellular signal-regulated kinase pathway. Cancer Res. 2009;69:9263-70.

62. Gu X, Coates PJ, Boldrup L, Nylander K. p63 contributes to cell invasion and migration in squamous cell carcinoma of the head and neck. Cancer Lett. 2008:263:26-34

63. Carroll DK, Carroll JS, Leong CO, Cheng F, Brown M, Mills AA, Brugge JS, et al. p63 regulates an adhesion programme and cell survival in epithelial cells. Nature Cell Biol. 2006:8:551-61.
64. Boldrup L, Coates PJ, Gu X, Nylander K. DeltaNp63 isoforms regulate CD44 and keratins 4, 6, 14 and 19 in squamous cell carcinoma of head and neck. J Pathol. 2007;213:384-91.

65. Cheung KJ, Gabrielson E, Werb Z, Ewald AJ. Collective invasion in breast cancer requires a conserved basal epithelial program. Cell. 2013;155:163951.

66. Lefkimmiatis K, Caratozzolo MF, Merlo P, D'Erchia AM, Navarro B, Levrero M,

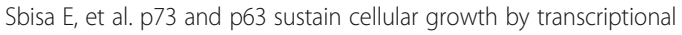
activation of cell cycle progression genes. Cancer Res. 2009;69:8563-71.

67. Senoo M, Pinto F, Crum CP, McKeon F. p63 is essential for the proliferative potential of stem cells in stratified epithelia. Cell. 2007;129:523-36.

68. Truong AB, Kretz M, Ridky TW, Kimmel R, Khavari PA. p63 regulates proliferation and differentiation of developmentally mature keratinocytes. Genes Dev. 2006;20:3185-97.

69. Dohn M, Zhang S, Chen X. p63alpha and DeltaNp63alpha can induce cell cycle arrest and apoptosis and differentially regulate p53 target genes. Oncogene. 2001;20:3193-205.

\section{Submit your next manuscript to BioMed Central and we will help you at every step:}

- We accept pre-submission inquiries

- Our selector tool helps you to find the most relevant journal

- We provide round the clock customer support

- Convenient online submission

- Thorough peer review

- Inclusion in PubMed and all major indexing services

- Maximum visibility for your research

Submit your manuscript at www.biomedcentral.com/submit
Biomed Central 